\title{
Analisis penerimaan retribusi dan strategi pengembangan objek wisata Taman Anggrek Sri Soedewi Provinsi Jambi
}

\author{
Aghniyah; *Syaparuddin; Erni Achmad \\ Program Studi Ekonomi Pembangunan Fak.Ekonomi dan Bisnis, Universitas Jambi \\ E-mail korespondensi : syappelawan@yahoo.co.id
}

\begin{abstract}
study aims to analyze retribution income of Taman Anggrek Sri Soedewi object and expected to produce a possible strategy that can be applied to increase the amount of retribution income in the tourism department of Anggrek Sri Soedewi Garden object in Jambi Province. In this research, used are is primary and secondary of data. This study usds data from the financial statements of tourism within 4 years from 2014 to 2018. The data were collected by questionnaire, observation, interview conducted to 21 respondents comprising of head division, and managements of tourism object, as well as visitors was selected by accidental sampling method. In SWOT matrix analysis, results obtained six alternative strategies, namely: (1) enhancement cooperation, (2) improving development program, (3) improving facilities and infrastructure, (4) allocation of human resources, (5) increasing a flower collection, and (6) increased promotion.
\end{abstract}

Keywords: Development Strategy, SWOT analysis, retribution income, tourism

\begin{abstract}
Abstrak
Penelitian ini bertujuan untuk menganalisis penerimaan retribusi obyek wisata Taman Anggrek Sri Soedewi serta diharapkan dapat menghasilkan strategi yang mungkin dapat diterapkan untuk meningkatkan jumlah pendapatan retribusi di departemen pariwisata objek Taman Anggrek Sri Soedewi di Provinsi Jambi. Dalam penelitian ini, data yang digunakan adalah data primer dan sekunder. Penelitian ini menggunakan data dari laporan keuangan pariwisata dalam waktu 4 tahun dari 2014 hingga 2018. Data dikumpulkan dengan kuesioner, observasi, wawancara yang dilakukan kepada 21 responden yang terdiri dari kepala divisi, dan manajemen dari objek wisata, serta pengunjung yang dipilih dengan metode purposive sampling. Dalam analisis matriks SWOT, hasil yang diperoleh enam strategi alternatif, yaitu: (1) meningkatkan kerja sama, (2) meningkatkan program pengembangan, (3) meningkatkan fasilitas dan infrastruktur, (4) alokasi sumber daya manusia, (5) meningkatkan koleksi bunga, dan (6) meningkatkan promosi.
\end{abstract}

Kata Kunci : Strategi pengembangan, analisis SWOT, penerimaan retribusi, pariwisata.

\section{PENDAHULUAN}

Pariwisata membawa perubahan pada perekonomian lokal. Pariwisata juga merupakan multisektoral dan saling mempengaruhi dengan sektor-sektor yang bersinggungan sehingga muncul keadaan dimana pariwisata akan meningkatkan pertumbuhan dan perkembangan serta minginjeksi keadaan ekonomi lokal. Pada 
kenyataanya, pariwisata mempunyai spektrum fundamental pembangunan yang lebih luas untuk suatu Negara (Utama, 2015).

Pariwisata sangat berpotensi besar dalam perekonomian, salah satunya dapat meningkatnya Pendapatan Asli Daerah (PAD) yang bersumber dari retribusi pariwisata yang ada di suatu daerah. Apabila semakin meningkat penerimaan retribusi maka semakin meningkat juga Pendapatan Asli Daerah. Sumber penerimaan daerah seperti Pendapatan Asli Daerah (PAD) diwujudkan di daerah dengan kewenangan memungut pajak dan retribusi daerah yang diatur dalam Undang-Undang Nomor 28 Tahun 2009 dengan peraturan pelaksanaannya berupa Peraturan Pemerintah Nomor 55 Tahun 2016 Tentang Pajak Daerah dan Peraturan Pemerintah Nomor 66 Tahun 2001 Tentang Retribusi Daerah.

Retribusi daerah sebagaimana halnya pajak merupakan salah satu Pendapatan Asli Daerah (PAD) yang di harapkan menjadi salah satu sumber pembiayaan penyelenggaraan pemerintah dan pembangunan daerah, untuk meningkatkan dan memeratakan kesejahteraan masyarakat. Suatu daerah yang memiliki banyak sumber penerimaan daerah maka daerah tersebut akan berkesempatan untuk meningkat pendapatan daerahnya (Kuncoro, 2012). Pengembangan adalah bakal tindakan yang menuntut keputusan manajemen puncak dalam pengembangan usaha untuk merealisasikannya. Disamping itu, strategi pengembangan juga mempengaruhi kehidupan organisasi dalam jangka panjang, paling tidak selama lima tahun. Strategi pengembangan mempunyai fungsi perumusan dan dalam mempertimbangkan faktorfaktor internal maupun eksternal yang dihadapi perusahaan/instansi pemerintahan (David, 2004).

Salah satu objek wisata di Provinsi Jambi yang menarik perhatian penulis adalah objek wisata Taman Angrek Sri Soedewi, dimana objek wisata ini dibangun di atas lahan seluas 2,5 hektar pada awal tahun 1984 oleh Prof.Dr.Soedewi Sofwan. Lokasinya berada di Jl.Ahmad Yani Kecamatan Telanaipura, Kawasan Taman Anggrek Sri Soedewi adalah salah satu sektor wisata yang merupakan salah satu komponen sumber penerimaan retribusi daerah sesuai dengan peraturan daerah Provinsi Jambi Nomor 6 tahun 2015 tentang retribusi jasa usaha, pada bagian BAB III Pemerintah Daerah Provinsi Jambi menyebutkan pada Pasal 14 bahwa Taman Anggrek Sri Soedewi adalah yang dimaksud dalam pasal 2 digolongkan sebagai Retribusi Jasa Usaha termasuk kedalam golongan Retribusi penjualan produksi usaha daerah yang didapat dari hasil penjualan karcis, penjualan bibit anggrek, dan sewa joglo.

Taman Anggrek Sri Soedewi memiliki potensi yang sangat kuat dimana letak nya sangat strategis namun hal ini tidak dapat meningkatkan jumlah kunjungan terbukti dengan penurunan jumlah kunjungan seiap tahunnya jumlah pengunjung Taman Anggrek Sri Soedewi pada tahun 2015 dengan jumlah 48,151 orang. Dan pada tahun 2015 ini merupakan posisi dengan jumlah pengunjung paling tinggi pada kurun waktu 4 tahun terakhir, namun pada tahun 2016 jumlah pengunjung menurun menjadi 21,247 orang, lalu pada tahun 2017 kembali mengalami penurunan sebesar 9,300 orang. dan pada tahun 2018 pengunjung Taman Anggrek Sri Soedewi mengalami kenaikan kembali sebesar 14,100 orang.

Tahun 2014 objek wisata Taman Anggrek mendapatkan realisasi sebesar Rp.120.760.000,00. Pada tahun 2015 menurun sebesar Rp.87.518.000,00 dari tahun ke tahun semakin menurun, pada tahun 2016 target yang dapat terealisasi menurun menjadi Rp.43.605.000,00. Lalu pada tahun 2017 menurun Rp.19.864.006,00 Hal ini dikarenakan target yang ditetapkan pemerintah terlalu tinggi dan tidak diiringi dengan strategi-strategi pengembangan terhadap objek wisata. Besarnya penerimaan retribusi 
di suatu daerah tentu tidak bisa dipisahkan dari kebijakan-kebijakan serta inovasi yang telah dilakukan oleh pemerintah, baik pemerintah pusat maupun pemerintah daerah itu sendiri terhadap sektor pariwisata yang dimilikinya. Maka diperlukan melakukan inovasi, strategi dan pengembangan objek wisata yang mampu memicu meningkatnya penerimaan retribusi daerah di Provinsi Jambi. Oleh karena itu diperlukan adanya suatu studi atau kajian tentang strategi pengembangan objek wisata.

Berdasarkan uraian diatas maka penulis tertarik untuk melakukan penelitian tentang "Analisis Penerimaan Retribusi dan Strategi Pengembangan Objek Wisata Taman Anggrek Sri Soedewi Provinsi Jambi" Dari latar belakang di atas maka permasalahan yang ingin dituntaskan dalam penelitian ini adalah sebagai berikut : (1) Seberapa besar efektivitas realisasi penerimaan retribusi objek wisata Taman Anggrek Sri Soedewi pada tahun 2014-2018 di Provinsi Jambi. (2) Seberapa besar kontribusi realisasi penerimaan retribusi objek wisata Taman Anggrek Sri Soedewi terhadap retribusi daerah pada tahun 2014-2018 di Provinsi Jambi. (3) Bagaimana strategi pengembangan untuk meningkatkan realisasi penerimaan retribusi objek wisata Taman Anggrek Sri Soedewi di Provinsi Jambi. Dan yang menjadi tujuan di dalam penelitian ini adalah sebagai berikut : (1) Menganalisis tingkat efektivitas realisasi penerimaan retribusi objek wisata Taman Anggrek Sri Soedewi pada tahun 2014-2018 di Provinsi Jambi. (2) Menganalisis kontribusi realisasi penerimaan retribusi objek wisata Taman Anggrek Sri Soedewi terhadap retribusi daerah pada tahun 2014-2018 di Provinsi Jambi. (3)Merumuskan strategi pengembangan guna meningkatkan realisasi penerimaan retribusi objek wisata Taman Anggrek Sri Soedewi di Provinsi Jambi.

\section{METODE}

Penelitian ini bersifat deskriptif kualitatif. Jenis data yang digunakan dalam penelitian ini adalah Data Primer dan data sekunder, data primer yang dipakai adalah data survey, wawancara, dokumentasi dan kuesioner. Sedangkan data sekunder adalah yang didapat dari Balai UPTD Taman Anggrek \& Kultur jaringan, Bakaeuda Provinsi Jambi, dan BPS Provinsi Jsmbi. Metode pengambilan data dengan menguunakan teknik accidental sampling yaitu dari Dinas UPTD Taman Anggrek 12 orang, Pedagang sekitar 1 orang, masyarakat sekitar objek wisata 1 orang, dan pengunjung objek wisata 7 orang. Metode yang digunakan untuk mengetahui pengaruh tingkat efektifitas dan kontribusi adalah sebagai berikut (Sumber : Halim, 2001) :

Efektifitas $=\begin{gathered}\text { Realisasi Penerimaan Retribusi Pariwisata } \times 100 \% \\ \text { Target Penerimaan Retribusi Pariwisata }\end{gathered}$

\section{Kontribusi $=$ Realisasi Penerimaan Retribusi Wisata $\quad$ x $100 \%$ \\ Realisasi Penerimaan Pendapatan Daerah}

Selanjutnya untuk menganalisis strategi pengembangan maka digunakan metode analisis SWOT yaitu menganalisis kekuatan, kelemahan, peluang dan ancaman, dalam penelitian ini penulis akan melakukan identifikasi faktor internal dan eksternal, tahap yang dilakukan selanjutnya adalah perumusan strategi. membuat tabel matriks IFAS dan EFAS, kemudian analisis IE dan SWOT masuk dalam tahap pencocokan serta memposisikan posisi objek wisata dengan matriks grand space analisis swot. 


\section{HASIL DAN PEMBAHASAN}

Efektifitas penerimaan retribusi Taman Anggrek Sri Soedewi Provinsi Jambi.

Penerimaan retribusi objek wisata diharapkan dapat memberikan kontribusi yang besar terhadap retribusi daerah sehingga dapat membantu meningkatkan perekonomian dan kesejahteraan masyarakat. Kebijaksanaan dalam pelaksanaan pembangunan daerah.Kebijaksanaan dalam pelaksanaan pembangunan daerah dimaksudkan untuk mengembangkan dan memberdayakan potensi wisata yang ada sebagai sumber penerimaan daerah yang nantinya digunakan dalam proses pembangunan daerah di Provinsi Jambi. Pemerintah dituntut untuk untuk melaksanakan pemungutan secara efektif di setiap objek pariwisata agar objek-objek pariwisata yang menjadi sumber penerimaan daerah mampu berkontribusi maksimal terhadap total penerimaan daerah di Provinsii Jambi.

Objek wisata Taman Anggrek Sri soedewi merupakan salah satu sumber penerimaan daerah yang berasal dari retribusi daerah sesuai dengan peraturan daerah Provinsi Jambi Nomor 6 tahun 2015 tentang retribusi jasa usaha, pada bagian BAB III Pemerintah Daerah Provinsi Jambi menyebutkan pada Pasal 14 bahwa Taman Anggrek Sri Soedewi adalah yang sebagaimana dimaksud dalam pasal 2 digolongkan sebagai Retribusi Jasa Usaha termasuk kedalam golongan Retribusi penjualan produksi usaha daerah yang didapat dari hasil penjualan karcis, penjualan bibit anggrek, dan sewa joglo. Dibawah ini merupakan tingkat efektifitas penerimaan retribusi :

Tabel .1. Efektifitas penerimaan retribusi objek wisata Taman Anggrek Sri Soedewi Provinsi Jambi Tahun 2014-2018.

\begin{tabular}{ccccc}
\hline Tahun & $\begin{array}{c}\text { Target } \\
\text { Penerimaan } \\
(\mathbf{R p})\end{array}$ & $\begin{array}{c}\text { Realisasi } \\
\text { Penerimaan } \\
(\mathbf{R p})\end{array}$ & $\mathbf{( \% )}$ & Kriteria \\
\hline 2014 & 60.000 .000 & $120.760 .000,00$ & 169 & Sangat Efektif \\
2015 & 80.140 .000 & $87.518 .000,00$ & 150,69 & Sangat Efektif \\
2016 & 92.000 .000 & $43.605 .000,00$ & 95,13 & Efektif \\
2017 & 92.000 .000 & $45.218 .000,00$ & 47,40 & Tidak Efektif \\
2018 & 107.000 .000 & 45.218 .000 & 42,26 & Tidak Efektif \\
\hline & & $\mathbf{1 0 1}$ & Sangat Efektif
\end{tabular}

Sumber : Data diolah, 2019

Hasil pada tabel 1 menunjukan bahwa rata-rata efektifitas penerimaan retribusi objek wisata Taman Anggrek Sri Soedewi dari tahun 2014 adalah 169 persen dengan kriteria sangat efektif, dikatakan sangat efektif karena persentase tingkat keefektivitasanya lebih dari $100 \%$, dengan kata lain kinerja pemungutan retribusi semakin baik. Dengan pencapian realisasi penerimaan sebesar Rp.101.402.000,sementara target yang ditetapkan hanya sebesar Rp.60.000.000,- hal ini berarti pencapaian target yang ditetapkan sangat baik. Lalu pada tahun 2015 memenuhi tingkat kriteria sangat efektif dengan persentase sebesar 150,96\%, dengan realisasi penerimaan yang agak mengalami peningkatan sebesar Rp.120.760.000,- dengan target pencapaian yang juga mengalami kenaikan sebesar Rp.80.140.000,--

Pada jangka 3 tahun terakhir realisasi penerimaan mengalami trend penurunan yaitu pada 2016 tingkat efektifitas hanya sebesar $95,13 \%$ dengan realisasi penerimaan 
sebesar Rp.87.518.000,- sementara target yang ditetapkan oleh pemerintah daerah sebesar Rp.92.000.000,- dengan kriteria rasio efektifitas sebesar 95,13\%. Dikatakan efektif karena rasio efektifitas masih berada diatas 90\%. Kemudian pada tahun 2017 mengalami penurunan kembali secara signifikan dengan persentase sebesar 47,39\% dengan kriteria tidak efektif. Dimana realisasi penerimaan hanya sebesar Rp.43.605.000,- sementara target yang ditetapkan berjumlah Rp.92.000.000,- Lalu Pada tahun 2018 mengalami sedikit penurunan sebesar 42,25\% dengan kriteria tidak efektif, dikarenakan kriteria tingkat efektifitas kurang dari $60 \%$.

Dapat dilihat dari tabel 5.1 bahwa realisasi penerimaan retribusi objek wisata pada tahun 2018 hanya sebesar Rp.45.218.000,- padahal target yang ditetapkan sebesar Rp.107.000.000,- hal inilah yang menjadi penyebab tingkat efektifitas pada tahun 2018 dikatakan tidak efektif yaitu sebesar 42,25\% dikarenakan rasio efektifitas tidak mencapai $60 \%$. Capaian target penerimaan yang paling efektif terjadi pada tahun 2014 yaitu sebesar 169 persen yang berarti target penerimaan sangat efektif tercapai, sedangkan capaian target yang paling rendah terjadi pada tahun 2018 sebesar 42,25\% dengan kriteria tidak efektif, yang berarti capaian penerimaan berada di bawah target yang telah ditetapkan yaitu pada tahun 2017 dan tahun 2018. Tidak efektifnya penerimaan retribusi di tahun 2017 dan 2018 dikarenakan pemerintah menetapkan target yang terlalu tinggi dengan harapan dapat tercapai dengan baik, namun tidak diiringi dengan adanya program maupun strategi-strategi pengembangan objek wisata.

\section{Kontribusi penerimaan retribusi Taman Anggrek Sri Soedewi terhadap retribusi daerah Provinsi Jambi.}

Besarnya penerimaan retribusi suatu objek wisata sangat diperlukan guna meningkatkan penerimaan retribusi terhadap total penerimaan retribusi daerah, salah satunya adalah dengan melalui strategi meningkatkan penerimaan retribusi daerah. Penerimaan retribusi objek wisata yang semakin meningkat akan memberikan kontribusi terhadap total penerimaan retribusi daerah yang semakin meningkat pula. Kontribusi retribusi objek wisata Taman Anggrek Sri Soedewi dihitung dengan membandingkan jumlah penerimaan retribusi objek wisata dengan jumlah retribusi daerah Provinsi Jambi, yang dapat digambarkan pada tabel 2 sebagai berikut :

Tabel .2. Kontribusi penerimaan retribusi objek wisata Taman Anggrek Sri Soedewi Provinsi Jambi Tahun 2014-2018.

\begin{tabular}{|c|c|c|c|c|}
\hline Tahun & $\begin{array}{c}\text { Retribusi Daerah } \\
\text { (Rp) }\end{array}$ & $\begin{array}{c}\text { Realisasi } \\
(\mathbf{R p})\end{array}$ & $\begin{array}{c}\text { Kontribusi } \\
(\%)\end{array}$ & Kriteria \\
\hline 2014 & 14.587 .180 .553 & 120.760 .000 & 0.69514 & Sangat Kurang \\
\hline 2015 & 19.336 .663 .877 & 87.518 .000 & 0.62451 & Sangat Kurang \\
\hline 2016 & 19.073 .840 .425 & 43.605 .000 & 0.45884 & Sangat Kurang \\
\hline 2017 & 19.854 .002 .006 & 45.218 .000 & 0.21963 & Sangat Kurang \\
\hline 2018 & 19.426 .452 .105 & 107.000 .000 & 0.23277 & Sangat Kurang \\
\hline \multicolumn{3}{|c|}{ Rata-rata } & 0.44618 & Sangat Kurang \\
\hline
\end{tabular}

Sumber : Data diolah, 2019 
Berdasrkan Tabel 2 diatas dapat dilihat bahwa penerimaan retribusi tahun anggaran 2014-2018 pemasukan realisasi penerimaan objek wisata Taman Anggrek Sri Soedewi terhadap retribusi daerah provinsi Jambi pertahunnya memiliki kontribusi yang masih kecil dan semakin menurun setiap tahunnya. Artinya, retribusi objek wisata Taman Anggrek belum mampu memberikan kontribusi yang bearti bagi retribusi daerah. Kontribusi terbesar objek wisata taman anggrek Sri Soedewi terhadap retribusi daerah ada pada tahun 2014 yaitu sebesar $0.69514 \%$ sedangkan kontribusi penerimaan terendah terhadap retribusi daerah terjadi pada tahun 2016 yaitu hanya sebesar $0.45884 \%$. Kontribusi rata-rata pendapatan realisasi objek wisata secara umum menunjukkan kecenderungan penurunan terhadap retribusi daerah di Provinsi Jambi dalam kurun waktu 2014 hingga 2018. Dimana pada tahun 2015 kontribusi hanya sebesar $0.62451 \%$, dengan realisasi penerimaan objek wisata berjumlah Rp.87.518.000,- terhadap penerimaan retribusi daerah yang berjumlah Rp. 19.336.663.877,- dengan kriteria kontribusi sangat kurang.

Berdasarkan dengan keadaan objek wisata yang kurang nya pengelolaan serta kurangnya strategi pengembangan dari pemerintah daerah. Dalam hal ini menyebabkan kontribusi sektor objek wisata terhadap retribusi daerah masih tergolong kecil dan menyebabkan penurunan setiap tahunnya. Maka dapat ditarik kesimpulan bahwa kontribusi yang diberikan oleh objek wisata Taman Anggrek Sri Soedewi adalah relatif tidak berperan terhadap retribusi daerah. Berdasarkan uraian diatas, dapat disimpulkan bahwa hasil rata-rata kontribusi retribusi objek wisata Taman Anggrek Sri Soedewi hanya sebesar $0.44618 \%$ dengan kriteria rata-rata sangat kurang. Dengan potensi besar kekuatan yang dimiliki oleh objek wisata Taman Anggrek Sri Soedewi merupakan suatu hal yang sangat disayangkan mengetahui bahwa kriteria hasil kontribusi yang dihasilkan masih sangat kurang. Kurang berkontribusinya realisasi penerimaan objek wisata terhadap retribusi disebabkan karena meningkatnya penerimaan retribusi daerah dari sektor lain yang tidak diikuti meningkatnya penerimaan pendapatan dari sektor wisata khususnya objek wisata Taman Anggrek Sri Soedewi.

Hal tersebut juga dapat disebabkan dalam pemungutan biaya retribusi tidak mencapai target yang sudah ditetapkan serta penambahan tingkat target yang akan dipungut. Kontribusi yang semakin kecil dan menurun tentu dapat mempengaruhi pemasukan penerimaan daerah yang berkontribusi langsung terhadap PAD, Besarnya kebijakan serta inovasi yang telah dilakukan oleh pemerintah, baik pemerintah pusat maupun pemerintah daerah itu sendiri terhadap sektor pariwisata yang dimilikinya. Maka diperlukan melakukan inovasi, strategi dan pengembangan objek wisata yang mampu memicu meningkatnya penerimaan retribusi daerah di Provinsi Jambi, lalu munculah pertanyaan bagaimana cara strategi pengembangan untuk meningkatkan realisasi penerimaan daerah tersebut. Hal ini tentu saja dibutuhkan kajian mendasar dari objek wisata Taman Anggrek Sri Soedewi itu sendiri. Menurut David (2004) menyatakan bahwa badan dan departemen pemerintah bertanggung jawab untuk merumuskan, menerapkan, dan mengevaluasi strategi-strategi yang menggunakan uang hasil pajak rakyat dengan seselektif mungkin untuk menyedikakan layanan dan program. 


\section{Analisis SWOT}

Adapun hasil dari pengolahan kuesioner yang telah dibagikan kepada responden kemudian diolah kedalam bentuk matriks IFAS dan EFAS sebagai berikut di bawah ini :

Tabel .3. Matriks IFAS objek wisata Taman Anggrek Sri Soedewi.

\begin{tabular}{|c|c|c|c|c|}
\hline $\begin{array}{c}\text { No. } \\
\text { I. }\end{array}$ & $\begin{array}{l}\text { Internal Factors Analysis } \\
\text { Kekuataan (Strength) }\end{array}$ & Rating & Bobot & $\begin{array}{c}\text { Rating X } \\
\text { Bobot }\end{array}$ \\
\hline S1 & Tempat yang strategis & 4 & 0.08 & 0.32 \\
\hline $\mathrm{S} 2$ & Harga tiket yang sangat terjangkau & 3 & 0.07 & 0.21 \\
\hline S3 & $\begin{array}{l}\text { Suasana objek wisata yang menarik } \\
\text { untuk tempat berswafoto }\end{array}$ & 3 & 0.07 & 0.21 \\
\hline $\mathrm{S} 4$ & Adanya transportasi yang mendukung & 3 & 0.07 & 0.21 \\
\hline S5 & Kebersihan dan kelestrian lingkungan & 3 & 0.07 & 0.21 \\
\hline S6 & Kaya akan jenis bunga anggrek & 3 & 0.07 & 0.21 \\
\hline $\mathrm{S} 7$ & $\begin{array}{l}\text { Semangat yang tinggi para pengelola } \\
\text { untuk mengembangkan objek wisata }\end{array}$ & 3 & 0.07 & 0.18 \\
\hline \multirow[t]{2}{*}{ S8 } & $\begin{array}{l}\text { Daya tarik kawasan diminati oleh } \\
\text { wisatawan semua umur }\end{array}$ & 3 & 0.07 & 0.21 \\
\hline & Total & & & 1.76 \\
\hline II. & Kelemahan (Weakness) & & & \\
\hline $\mathrm{W} 1$ & Promosi yang belum optimal & 3 & 0.06 & 0.18 \\
\hline $\mathrm{W} 2$ & $\begin{array}{l}\text { Program pengembangan yang masih } \\
\text { sederhana }\end{array}$ & 3 & 0.06 & 0.18 \\
\hline W3 & Sarana \& Prasarana kurang memadai & 2 & 0.05 & 0.15 \\
\hline W4 & Jumlah Pengelola yang masih kurang & 2 & 0.05 & 0.15 \\
\hline W5 & Keterbatasan anggaran & 2 & 0.05 & 0.10 \\
\hline W6 & Kurangnya dukungan pemerintah & 2 & 0.05 & 0.10 \\
\hline W7 & Kualitas SDM yang rendah & 2 & 0.04 & 0.08 \\
\hline W8 & $\begin{array}{l}\text { Pemasukan retribus belum mencapai } \\
\text { target }\end{array}$ & 2 & 0.05 & 0.10 \\
\hline \multicolumn{2}{|r|}{ Total } & & 1.00 & $\begin{array}{l}1.04 \\
2.80\end{array}$ \\
\hline
\end{tabular}

Sumber : Data primer (diolah), 2019

Berdasarkan tabel 3 Matriks IFAS Objek Wisata Taman Anggrek Sri Soedewi. menunjukkan bahwa faktor kekuataan dari objek wisata taman anggrek yang paling dominan adalah S1 yaitu tempat yang sangat strategis dengan total skor 0.08 yang bearti rating 4 dari faktor internal kekuatan tersebut mengindikasikan bahwa persepsi responden rata-rata terhadap faktor tersebut sangat kuat dan berpengaruh besar mempengaruhi posisi strategis objek wisata, serta faktor tersebut memiliki tingkat kepentingan yang tinggi untuk mempengaruhi posisi strategis objek wisata, dimana faktor kelemahan paling tinggi terletak di W1 promosi yang belum optimal dengan skor 0.06 , artinya rata-rata persepsi responden secara umum menilai bahwa objek wisata Taman Anggrek masih sangat kurang dalam hal promosi dan faktor kelemahan yang paling dominan terletak di W2 Program pengembangan yang masih sederhana dengan skor 0.06 hal ini menunjukkan bahwa persepsi responden rata-rata menilai bahwa program pengembangan di Taman Anggrek masih sederhana dan faktor tersebut sangat berpengaruh besar terhadap kelangsungan objek wisata.

Hasil total skor dari bobot X Rating 2.80 dimana kondisi faktor internal dari kekuatan 1.76 yang artinya faktor internal objek wisata masih memiliki andil terhadap 
faktor kelemahan dengan skor 1.04. Hal ini mengindikasikan bahwa objek wisata Taman Anggrek Sri Soedewi memiliki posisi yang masih kuat untuk bertahan dan terus berkembang yang artinya objek wisata harus terus menerus beradaptapsi dengan setiap perubahan di dalam lingkungan yang kompetitif, yang di dalam dirinya sendiri terus berubah dengan laju yang terus bertambah. Tidak hanya bereaksi terhadap perubahan namun perlu untuk mengantisipasi perubahan dan idealnya menjadi penggagas dari perubahan tersebut serta meihat perubahan sebagai proses yang berkelanjutan dan tidak stagnan.

Tabel .4. Matriks EFAS objek wisata Taman Anggrek Sri Soedewi.

\begin{tabular}{|c|c|c|c|c|}
\hline $\begin{array}{c}\text { No. } \\
\text { I. }\end{array}$ & $\begin{array}{l}\text { Eksternal Factors Analysis } \\
\text { Peluang (Opportunity) }\end{array}$ & Rating & Bobot & $\begin{array}{c}\text { RatingX } \\
\text { Bobot }\end{array}$ \\
\hline O1 & Meningkatnya investasi swasta & 3 & 0.07 & 0.21 \\
\hline $\mathrm{O} 2$ & Sektor pariwisata yang semakin berkembang & 3 & 0.08 & 0.24 \\
\hline $\mathrm{O} 3$ & Menambah lapangan pekerjaan & 3 & 0.08 & 0.24 \\
\hline $\mathrm{O} 4$ & $\begin{array}{l}\text { Omongan atau opini positif dari wisatawan ke } \\
\text { orang lain }\end{array}$ & 3 & 0.08 & 0.24 \\
\hline O5 & Menjadi Ruang Terbuka Hijau & 4 & 0.09 & 0.36 \\
\hline O6 & Teknologi yang semakin berkembang & 3 & 0.09 & 0.24 \\
\hline \multirow[t]{3}{*}{$\mathrm{O} 7$} & Otonomi daerah memberi keleluasaan untuk & 3 & 0.08 & 0.24 \\
\hline & $\begin{array}{l}\text { mengembangkan potensi wisata yang } \\
\text { dimilikinya }\end{array}$ & 3 & 0.08 & 0.24 \\
\hline & Total & & & 1.77 \\
\hline II. & Ancaman (Treat) & & & \\
\hline T1 & Berkembangnya taman kota gratis tanpa tarif & 3 & 0.07 & 0.21 \\
\hline $\mathrm{T} 2$ & Persaingan dengan objek wisata lain & 3 & 0.07 & 0.21 \\
\hline $\mathrm{T} 3$ & $\begin{array}{l}\text { Kesadaran wisatawan untuk menjaga objek } \\
\text { wisata }\end{array}$ & 2 & 0.05 & 0.10 \\
\hline $\mathrm{T} 4$ & $\begin{array}{l}\text { Kurangnya dukungan pemerintah daerah } \\
\text { (Dalam promosi dan sarana dan prasarana) }\end{array}$ & 2 & 0.05 & 0.10 \\
\hline T5 & Pencemaran lingkungan & 2 & 0.06 & 0.12 \\
\hline T6 & Berkurangnya minat wisatawan & 3 & 0.06 & 0.18 \\
\hline \multirow[t]{2}{*}{$\mathrm{T} 7$} & Terjadinya bencana/gangguan alam & 3 & 0.07 & 0.21 \\
\hline & Total & & 1.00 & $\begin{array}{c}1.13 \\
2.9 \\
\end{array}$ \\
\hline
\end{tabular}

Sumber : Data primer (diolah), 2019

Hasil dari tabel 4 Matriks EFAS Objek Wisata Taman Anggrek Sri Soedewi, mengindikasikan bahwa faktor peluang dari objek wisata Taman Anggrek yang paling dominan adalah O5 menjadi Ruang Terbuka Hijau dengan skor 0.09, hal ini mengindikasikan bahwa persepsi rata-rata responden terhadap peluang pada O5 Menjadi Ruang Terbuka Hijau merupakan peluang yang sangat berpengaruh besar terhadap kemajuan objek wisata kedepannya. Faktor ancaman paling tinggi terletak di T1 Berkembannya taman kota gratis tanpa tarif ,T2 Persaingan dengan objek wisata lain, dan T7 Terjadinya bencana/gangguan alam. Hal ini mengindikasikan bahwa faktor ancaman yang paling berbahaya dan sangat mempengaruhi objek wisata adalah persaingan dengan objek wisata lain yang tidak menggenakan tarif masuk retribusi selayaknya RTH lainnya seperti taman jomblo dan taman jaksa sejenisnya. Lalu faktor 
gangguan alam disini dipersepsikan oleh responden seperti misalnya kabut asap yang baru-baru ini sedang rawan di Provinsi Jambi membuat persepsi responden sangat berpengaruh terhadap berkurangnya jumlah tingkat kunjungan para wisatawan di Taman Anggrek.

Lalu total skor ancaman paling rendah didapat di T3 Kesadaran wisatwan untuk menjaga objek wisata dan T4 kurangnya dukungan pemerintah Daerah, Hal ini bearti persepsi responden terhadap kedua ancaman tersebut kurang berpengaruh dan kurang mempengaruhi terhadap posisi objek wisata. Total skor dari Peluang adalah 1,77 dibandingkan dengan faktor ancaman hanya mendapat nilai 1.13, maka nilai yang dapat dijadikan dasar kebijakan adalah nilai kesempatan (Opportunity). Matriks IE merupakan matriks yang tujuannya untuk memperoleh strategi objek di tingkat koorporat yang lebih detail. Analisis matriks IE dalam penelitian ini dapat digambarkan sebagai berikut:

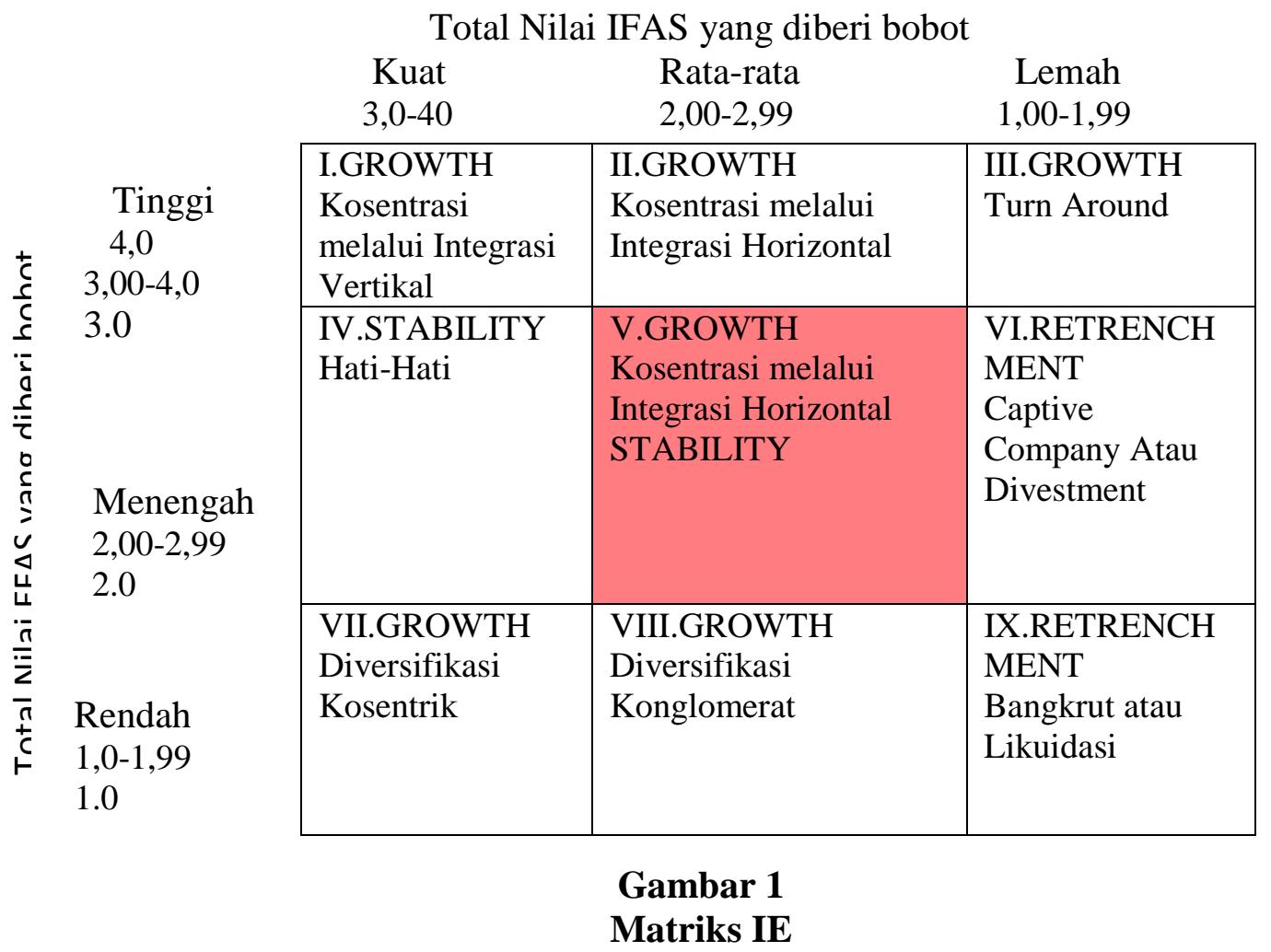

Berdasarkan dari hasil tabel matrix IFAS dan tabel Matriks EFAS, diketahui bahwa total skor nilai IFAS secara keseluruhan adalah 2.80 dan nilai total skor EFAS adalah 2.9. Jadi analisis SWOT yang diterapkan untuk analisis strategi dan mengetahui posisi unit usaha adalah berada di sel nomor lima (growth) yaitu posisi dimana suatu unit usaha mengalami suatu masa pertumbuhan. Hal ini juga dapat dicapai dengan integrazi horizontal yaitu mengupayakan kepemilikan atau kendali yang lebih besar atas pesaing. Serta menjaga dan memanfaatkan potensi kekuatan sumber daya yang ada untuk meminimalkan kelemahan. Merger, akuisisi, dan pengambilalihan (take over) diantara para pesaing memungkinkan peningkatan skala ekonomi serta mendorong transfer sumber daya dan kompetensi.Objek wisata Taman Anggrek Sri Soedewi memiliki daya tarik sedang, jadi strategi yang diterapkan adalah konsilidasi. Tujuannya relative dan defensive, yaitu menghindari kehilangan pengunjung dan profit. Usaha yang berada pada sel ini bisa memperluas strategi budidaya anggrek yang bagus serta penerapan tekhnologi untuk mengembangkan internal dan eksternal objek wisata Taman 
Anggrek Sri Soedewi (David, 2004).

Berdasarkan hasil dari tabel matriks IFAS dan EFAS yang telah diolah dari hasil kuesioner yang dibagikan dan di isi oleh responden maka dapat diketahui bahwa nilai IFAS nya adalah 2.80 yang artinya objek wisata Taman Anggrek Sri Soedewi berada pada titik rata-rata dalam posisinya menjalankan strategi memanfaatkan kekuatan untuk mengatasi kelemahan. Nilai dari total skor EFAS didapat 2.9 yang bearti objek wisata Taman Anggrek Sri Soedewi berada pada posisi untuk menjalankan strategi memanfaatkan peluang untuk mengatasi ancaman. Selanjutnya nilai total skor dari masing-masing faktor adalah Kekuatan 1.76, Kelemahan 1.04, Peluang 1.77, Ancaman 1.13. Selanjutnya diketahui selisih total skor faktor kekuatan dan kelemahan adalah $(+)$ 0.72 , sedangkan selisih total skor faktor peluang dan ancaman adalah sebesar (+) 0.64. Digunakan formulasi sumbu $\mathrm{X}$ dan $\mathrm{Y}$, dimana sumbu $\mathrm{X}$ adalah EFAS (PeluangAncaman) dan sumbu $\mathrm{Y}$ adalah IFAS (Kekuatan-Kelemahan) yang dinyatakan dengan nilai sesuai hasil skoring. Jadi titik koordinatnya (x,y) 0.72 dan 0.64. Maka Hasil analisis dapat digambarkan ke dalam Matriks SPACE sebagai berikut (Sumber : David, 2004) :

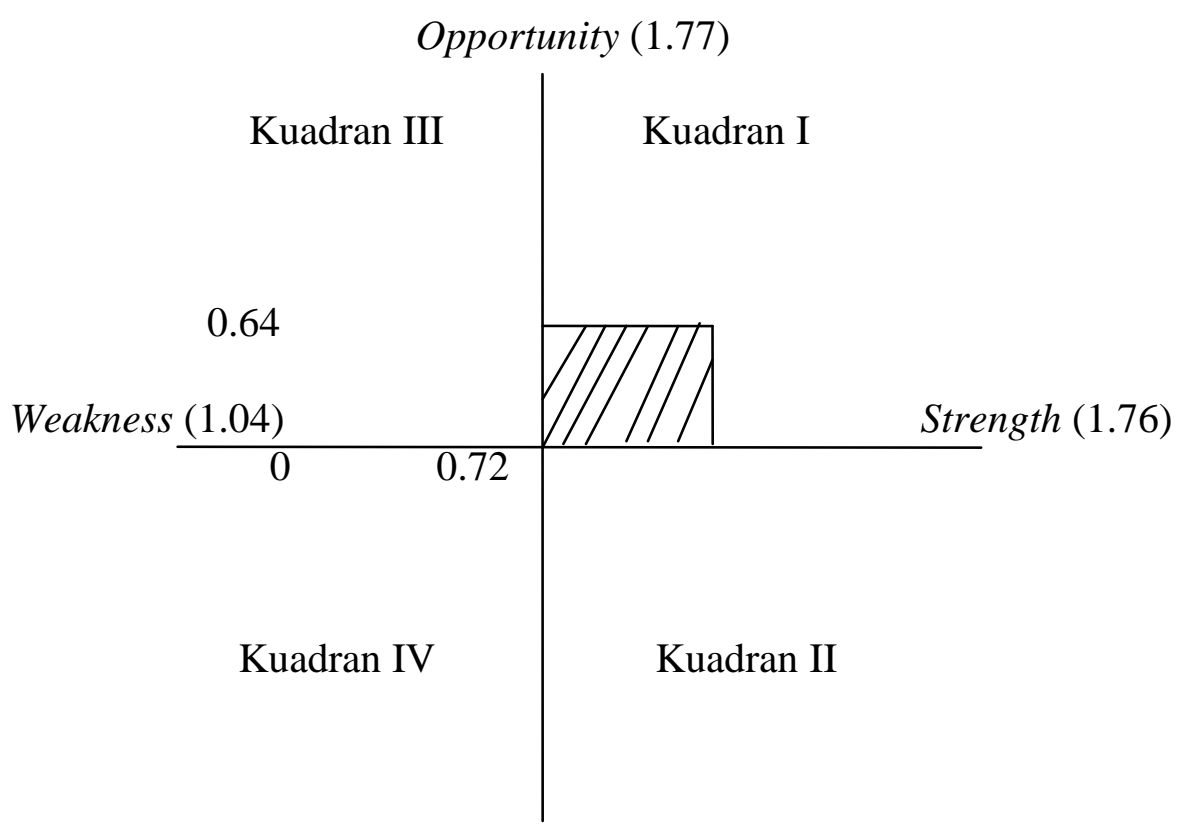

Threat (1.13)

Gambar 2

Matriks SPACE

Strategi yang harus diterapkan dalam kondisi tersebut adalah mendukung kebijakan pertumbuhan agresif (Growth Oriented Strategy). Strategi ini mengindikasikan keadaan objek wisata yang kuat dan mampu untuk terus berkembang dengan mengambil kesempatan atau peluang yang ada untuk meraih penerimaan retribusi yang dapat mencapai target. 
Tabel .5. Matriks SWOT

\begin{tabular}{|c|c|c|}
\hline & STRENGTH & WEAKNESS \\
\hline EFAS & $\begin{array}{l}\text { 1. Tempat yang strategis } \\
\text { 2. Harga tiket yang terjangkau } \\
\text { 3. Suasana objek wisata yang } \\
\text { menarik untuk berswafoto } \\
\text { 4. Adanya transportasi yang } \\
\text { mendukung } \\
\text { 5. Kebersihan dan kelestraian } \\
\text { lingkungan } \\
\text { 6. Kaya akan jenis bunga } \\
\text { anggrek } \\
\text { 7. Semangat yang tinggi para } \\
\text { pengelola } \\
\text { 8. Daya tarik kawasan untuk } \\
\text { semua umur }\end{array}$ & $\begin{array}{l}\text { 1. Pemasaran objek wisata } \\
\text { belum optimal } \\
\text { 2. Program pengembangan } \\
\text { yang masih sederhana } \\
\text { 3. Sarana \& prasarana } \\
\text { kurang memadai } \\
\text { 4. Jumlah pengelola masih } \\
\text { kurang } \\
\text { 5. Keterbatasan anggaran } \\
\text { 6. Kurangnya dukungan } \\
\text { pemerintah } \\
\text { 7. Kualitas SDM yang } \\
\text { rendah } \\
\text { 8. Pemasukan retribusi yang } \\
\text { belum mencapai target }\end{array}$ \\
\hline OPPORTUNITY & STRATEGI SO & STRATEGI WO \\
\hline $\begin{array}{l}\text { 1. Meningkatnya } \\
\text { investasi swasta } \\
\text { 2. Sektor pariwisata yang } \\
\text { semakin berkembang } \\
\text { \& diminati } \\
\text { 3. Menambah lapangan } \\
\text { pekerjaan } \\
\text { 4. Omongan atau opini } \\
\text { positif dari orang lain } \\
\text { 5. Menjadi Ruang } \\
\text { Terbuka Hijau } \\
\text { 6. Tekhnologi yang } \\
\text { semakin berkembang } \\
\text { 7. Otonomi daerah } \\
\text { memberi keleluasan } \\
\text { untuk mengembangkan } \\
\text { potensi wisata yang } \\
\text { dimilikinya }\end{array}$ & $\begin{array}{l}\text { 1. Letak yang strategis dapat } \\
\text { menarik swasta maupun } \\
\text { pihak diluar untuk } \\
\text { berinvestasi dan bekerja } \\
\text { sama } \\
\text { 2. harga tiket yang terjangkau } \\
\text { dapat memicu minat } \\
\text { masyarakat } \\
\text { 3. Adanya transportasi yang } \\
\text { mendukung akan } \\
\text { mendorong warga semakin } \\
\text { mudah megakses dan } \\
\text { memicu opini positif } \\
\text { 4. Kebersihan dan kelestarian } \\
\text { lingkungan yang terjaga } \\
\text { merupakan syarat utama } \\
\text { Ruang Terbuka Hijau } \\
\text { 5. Kekayaan koleksi bunga } \\
\text { anggrek dapat } \\
\text { dimaanfaatkan dengan } \\
\text { tekhnologi yang semakin } \\
\text { berkembang untuk } \\
\text { membudidayakannya } \\
\text { 6. Semangat yang tinggi para } \\
\text { penggelola sangat potensial } \\
\text { dimana Otonomi daerah } \\
\text { memberikan keleluasaan } \\
\text { langsung untuk mengurus } \\
\text { sumber daya yang dimiliki }\end{array}$ & $\begin{array}{l}\text { 1. Meningkatkan kerjasama } \\
\text { dengan pihak-pihak } \\
\text { terkait sekaligus wahana } \\
\text { untuk meningkatkan } \\
\text { promosi } \\
\text { 2. Meningkatkan program } \\
\text { pengembangan objek } \\
\text { wisata sehingga sector } \\
\text { priwisata semakin } \\
\text { diminati } \\
\text { 3. Memperbaiki } \\
\text { sarana\&prasarana } \\
\text { sehingga juga dapat } \\
\text { membuka lapangan } \\
\text { pekerjaan } \\
\text { 4. Menambah staff } \\
\text { pengelola sehingga hasil } \\
\text { output menjadi baik, lalu } \\
\text { akan menimbulkan opini } \\
\text { positif dari masyarakat. } \\
\text { 5. Meningkatkan biaya } \\
\text { anggaran untuk } \\
\text { menambah wahana RTH } \\
\text { 6. Meningkatkan kualitas } \\
\text { SDM yang mumpuni } \\
\text { dengan memanfaatkan } \\
\text { peluang yaitu dengan } \\
\text { menggunakan hak } \\
\text { otonom dengan sebaik- } \\
\text { baiknya }\end{array}$ \\
\hline
\end{tabular}




\begin{tabular}{|c|c|c|}
\hline THREAT & SRTATEGI ST & STRATEGI WT \\
\hline $\begin{array}{l}\text { 1. Berkembangnya taman } \\
\text { kota gratis tanpa tarif } \\
\text { 2.Persaingan dengan } \\
\text { objek wisata lain } \\
\text { 3. Kesadaran wisatawan } \\
\text { untuk menjaga objek } \\
\text { wisata } \\
\text { 4. Kurangnya dukungan } \\
\text { pemda (dalam promosi } \\
\text { dan sarana\&prasarana) } \\
\text { 5.Pencemaran } \\
\text { lingkungan } \\
\text { 6. Berkurangnya minat } \\
\text { wisatawan } \\
\text { 7.Terjadinya bencana } \\
\text { atau gangguan alam }\end{array}$ & $\begin{array}{l}\text { 1. Tempat yang strategis dan } \\
\text { menarik untuk berswafoto } \\
\text { merupakan potensi yang } \\
\text { tepat untuk menghindari } \\
\text { ancaman dari timbulnya } \\
\text { taman kota tanpa tarif } \\
\text { 2. Harga yang terjangkau } \\
\text { dapat menjadi daya saing } \\
\text { yang kuat untuk bersaing } \\
\text { dengan objek wisata lain } \\
\text { 3. Meningkatkn ketersediaan } \\
\text { transportasi umum } \\
\text { 4. Meningkatkan koleksi } \\
\text { bunga akan menghindari } \\
\text { ancaman berkurangnya } \\
\text { minat wisatawan }\end{array}$ & $\begin{array}{l}\text { 1. Meningkatkan program } \\
\text { pengembangan agar dapat } \\
\text { bersaing dengan objek } \\
\text { wisata lain } \\
\text { 2. Meningkatkan anggaran } \\
\text { untuk menambah tenaga } \\
\text { pengelola maupun } \\
\text { petugas kebersihan } \\
\text { sehingga pencemaran } \\
\text { lingkungan yang dapat } \\
\text { mengakibatkan } \\
\text { berkurangnya minat } \\
\text { wisatawan dapat } \\
\text { dihindari }\end{array}$ \\
\hline
\end{tabular}

Sumber : Data primer (diolah), 2019

Dari hasil analisis SWOT diatas, maka ada beberapa strategi yang didapat, yaitu sebagai berikut :

\section{Strategi SO (Strength and Opportunity)}

a. Letak yang strategis dapat menarik swasta maupun pihak diluar untuk berinvestasi dan bekerja sama.

b. harga tiket yang terjangkau dapat memicu minat masyarakat.

c. Adanya transportasi yang mendukung akan mendorong warga semakin mudah megakses dan memicu opini positif.

d. Kebersihan dan kelestarian lingkungan yang terjaga merupakan syarat utama Ruang Terbuka Hijau.

e. Kekayaan koleksi bunga anggrek dapat dimaanfaatkan dengan tekhnologi yang semakin berkembang untuk membudidayakannya.

f. Semangat yang tinggi para penggelola sangat potensial dimana otonomi daerah memberikan keleluasaan langsung untuk mengurus sumber daya yang dimiliki.

\section{Strategi WO (Weakness and Opportunity)}

a. Meningkatkan kerjasama dengan pihak-pihak terkait sekaligus wahana untuk meningkatkan promosi.

b. Meningkatkan program pengembangan objek wisata sehingga sektor priwisata semakin diminati.

c. Memperbaiki sarana \& prasarana yang telah rusak.

d. Menambah staff pengelola sehingga hasil output menjadi baik, lalu akan menimbulkan opini positif dari masyarakat.

e. Meningkatkan biaya anggaran untuk menambah wahana RTH.

f. Meningkatkan kualitas SDM yang mumpuni dengan memanfaatkan peluang yaitu dengan menggunakan hak otonom dengan sebaik-baiknya. 


\section{Strategi ST (Strength and Threat)}

a. Tempat yang strategis dan menarik untuk berswafoto merupakan potensi yang tepat untuk menghindari ancaman dari timbulnya taman kota tanpa tarif.

b. Harga yang terjangkau dapat menjadi daya saing yang kuat untuk bersaing dengan objek wisata lain.

c. Meningkatkn ketersediaan transportasi umum.

d. Meningkatkan koleksi bunga akan menghindari ancaman berkurangnya minat wisatawan.

\section{Strategi WT (Weakness and Threat)}

a. Meningkatkan program pengembangan agar dapat bersaing dengan objek wisata lain.

b. Meningkatkan anggaran untuk menambah tenaga pengelola maupun petugas kebersihan sehingga pencemaran lingkungan yang dapat mengakibatkan berkurangnya minat wisatawan dapat dihindari.

\section{KESIMPULAN DAN SARAN}

\section{Kesimpulan}

Efektifitas penerimaan retribusi objek wisata Taman Anggrek Sri Soedewi Provinsi Jambi tahun 2014-2018 sebesar $101 \%$ dengan kriteria rata-rata sangat efektif. Kontribusi penerimaan objek wisata pada tahun 2014-2018 terhadap retribusi daerah memiliki rata-rata kontribusi sebesar $0.44618 \%$ dengan kriteria rata-rata kontribusi sangat kurang. Berdasarkan hasil analisis SWOT strategi-strategi yang tepat adalah mengupayakan kepemilikan atau kendali yang lebih besar atas pesaing. Dari ke 4 sel strategi SWOT maka didapatlah strategi-strategi sebagai berikut : 1) Meningkatkan kerjasama dengan pihak-pihak terkait, 2) Meningkatkan program pengembangan objek wisata, 3) Memperbaiki sarana \& prasarana, 4) Menambah staff pengelola, 5) Menambah koleksi bunga, 6) Meningkatkan promosi.

\section{Saran}

Pemerintah diharapkan mampu membuat strategi-strategi yang inovatif serta memiliki daya saing yang kuat dan unik yang tidak dapat ditemukan di objek wisata lain. Pemerintah juga hendaknya fokus dan serius dalam hal ini karena potensi trend pariwisata berbasis taman buatan alam yang sangat berkembang belakangan ini, setidaknya pemerintah Provinsi Jambi bisa belajar dan terinspirasi dari taman-taman yang dimiliki oleh daerah lainnya di Indonesia dalam hal pengembangan dan kreasi. Pemerintah Provinsi Jambi harus mampu memenuhi target penerimaan yang telah ditetapkan dan harus mampu meningkatkan kontribusi objek wisata terhadap total penerimaan retribusi daerah. Selanjutnya pemerintah Provinsi Jambi harus segera memenuhi unsur-unsur dasar pengelolaan objek wisata agar meningkatkan kunjungan wisatawan yang selanjutnya akan berdampak kepada meningkatnya penerimaan retribusi objek wisata itu sendiri.

\section{DAFTAR PUSTAKA}

Badan Pusat Statistik. (2017). PAD dan Retribusi Daerah. BPS. Provinsi Jambi. Bungin. (2015). Komunikasi Pariwisata. Kencana Prenada Media : Jakata.

Cranz \& Boland. (2004). Mendefinisikan Taman Berkelanjutan : Model Kelima untuk Taman Perkotaan Landscape. E-Journal. University Of Wisconsin. 
David. (2004). Manajemen Strategis : Konsep . Edisi ketujuh. PT. Prenhallindo : Jakarta.

Danamik, Weber. (2006). Perencanaan Ekowisata Dari Teori ke Aplikasi. PUSPAR UGM dan Andi : Yogyakarta.

Elly. (2011). Pengaruh Pajak Daerah dan Retribusi Daerah Terhadap Pendapatan Asli Daerah Serta Implikasinya Pada Sektor Publik. Economic Development Journal. UNES.

Halim, (2001). Manajemen Keuangan Daerah.UPP AMP YKPN : Yogyakarta.

Hakim, Rustam. (2012). Komponen Perancangan Arsitektur Lansekap :Prinsip UnnsurUnsur dan Aplikasi. Bumi Aksara : Jakarta.

Idris. (2016). Potential Increase In Revenue Collection. BPHTB Tax District Musi Banyuasin. European Journal Of Accounting, Auditing And Finance Research, Vol.4 (1).

Mardiasmo. (2018). Perpajakan, Edisi 2018. Andi Publisher : Yogyakarta.

Natalia. (2015). Analisis Penerimaan Retribusi Objek Wisata Gucci Kabupaten Tegal. Jurnal Ekonomi Pembangunan. Universitas Diponegoro.

Pendit. (2002). Ilmu Pariwisata Sebuah Pengantar Perdana. PT.Pradnya Paramita : Jakarta.

Peraturan Pemerintah (2001). Nomor 66 Tahun 2001 Tentang Retribusi Daerah. Sekretariat Negara Jakarta.

Rayhan, Muhammad. (2017). Analisis Penerimaan Retribusi Sektor Pariwisata Kabupaten Kerinci. Skripsi. Universitas Jambi.

Rangkuti. (2004). Analisis SWOT Teknik Membeda Kasus Bisnis. PT Gramedia : Jakarta.

Spillane. (1994). Pariwisata Indonesia Siasat Ekonomi dan Rekayasa Budaya. Kanisius : Yogyakarta.

Umar, Husein. 2001). Riset Sumber Daya Manusia Dalam Organisasi. Gramedia Pustaka Utama : Jakarta.

Utama. (2017). Pemasaran Pariwisata. Andi : Yogyakarta.

Wahab, Salah. (2003). Industri Pariwisata dan Peluang Kesempatan Kerja. PT. Pertja : Jakarta.

Yoeti, Oka. (2010). Dasar-dasar Pengertian Hospitalty Pariwisata. PT.Alumni : Bandung. 